\title{
Eastern European Business Case Study In Entrepreneurship
}

Shelly A. Daly, Lindenwood University, USA

Mariia Les, MBA Student, Lindenwood University, USA

\begin{abstract}
This case looks at the new and continually evolving environment of capitalism and business in the Ukraine. While the Ukraine business environment shares key characteristics of other Eastern European markets, it is also distinct and unique in its challenges, products and people. A specific industry and entrepreneur offer insights and information that allow for understanding the opportunities present in this and similar markets.
\end{abstract}

Keywords: International Business Case Study; Entrepreneurship Business Case Study; Eastern European Business Case Study

\section{INTRODUCTION}

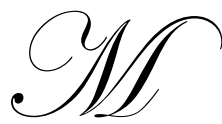

ihail Petrov saw his opportunity in 1997 to begin a business. While the idea of becoming an entrepreneur was a bit daunting, he was still young enough to start small and allow the business to grow slowly. He wanted to build his company from the ground up and be able to pass it down to his sons. He was old enough to remember the days of communist business models that his own father and grandfather had worked under. Mihail had lived his whole life in Ukraine and had not travelled much outside of his home country. He had spent time reading and studying and trying to learn about this new capitalist idea that his country now embraced. He felt fully aware of the problems and issues and rampant corruption that existed due to the monumental changes that had taken place in Ukraine. However, living in the capital, he also felt that opportunities were as good as they were going to get and that it was time to try his hand as a small business owner.

Mihail spent the first year of his life as a business man developing a relationship with Andrey Kulikov, the local governor, who helped him build and maintain the important political connections needed to survive in the Ukrainian business world. Corruption was a fact of life and was considered 'manageable' as long as you understood the rules, both formal and informal, and did not make yourself too important.

For the next seven years Mihail was successful and happy. His average income about $\$ 6000$ per year, he raised his family, saved enough to begin building a home in the suburbs surrounding the city and supported his parents financially. Like many people of his parent's generation, poor healthcare and life-long hardships under communism had led to a situation where they were unable to work despite being in their early fifties. Government pensions and assistance were basically nonexistent.

\section{THE BUSINESS}

\section{The First Years}

Mihail purchased wood from local Ukrainian factories. He then processed it and applied a veneer coating to the wood and arranged for exporting it to non-Ukrainian furniture manufacturers. For seven years, his business saw a steady increase in operations. He did not advertise or travel and relied on word of mouth referrals. New customers sought him out and existing customers steadily increased their purchases. He shipped his processed lumber to Poland, Italy, Germany, and France. 
After the first ten years in business, Mihail was able to hire a translator to help him improve customer communications. Up to this point, contracts were very informal and his English was good enough to write emails and understand what the customer requirements were. However, he was not confident to handle increasingly larger contracts, phone calls, or the idea that larger orders from larger companies may come with more detailed specifications that went beyond his basic skills to communicate effectively in English.

\section{Legalities}

In 2009 the Ukrainian government passed a new law written specifically to affect the harvesting and use of native wood supplies. These wood supplies were Mihail's only source of lumber for his business. His suppliers were directly and immediately affected and no one was prepared for the impact of a hastily written and enforceable law.

The law essentially held that for every tree cut down, a certain number of trees must be planted. The exact number and location of replacement trees varied based on region, age of existing trees and type of wood being harvested. Although the law did not directly affect the way Mihail would do business, he knew that it would affect costs and availability. He may not be able to order specific types of lumber as easily as before the law went into effect. Additionally, he may not be able to accurately quote prices to his customers since the impact to his suppliers was still such a large unknown. Mihail feared a long term situation where prices would steadily edge higher and higher and available supplies would became unpredictable. Mihail hoped his loyalty and ongoing relationships with lumber suppliers would prove sound enough to help him through this transition period. He believed the law was probably a good one, but it was being implemented very quickly with little forethought on helping businesses transition and plan.

\section{A New Reality}

Very quickly Mihail felt the impact of a reduced supply. His business partners in the supply chain were simply unable to harvest enough lumber to fulfill existing demand, much less increasing demand. Mihail began spending the majority of his business day searching out new supply sources and sales dropped rapidly as his unfilled orders were pulled back and customers went elsewhere. Even if a new supplier outside Ukraine became known to Mihail, he was rushed to order and was unused to doing business prior to building a relationship. The situation, demands and stress of changing his business model was quickly taking its toll. However, after a turbulent year, Mihail felt like his business was back on stable ground by the middle of 2010. He still felt the disconcerting effects of using suppliers whom he had not had the opportunity to build a relationship with. Additionally, all of his closely cultivated relationships with Ukrainian government officials were much less important when the bulk of his raw lumber came from outside of his national boundaries.

Once day-to-day operations stabilized, Mihail turned his attention to thinking about the long term effects of sourcing outside of Ukraine. Despite the additional cost of importing raw lumber across national boundaries, he was able to make a profit and maintain a steady level of production and exporting. However, he knew that at any time, tariffs or quotas on imported lumber could send his business into a realm of new uncertainty. After much thought, Mihail felt strongly that the best long term alternative was to partner with Ukrainian suppliers and build his business based on that supply market.

\section{Tax Reform}

Just when things had stabilized and Mihail felt as though he had time to reevaluate his business plan, a tax reform directly aimed at the small business owner took effect. The new law stated that any business with a gross profit over $\$ 37,322$ per year would be subjected to a 'common' tax. Under Ukrainian law, the common tax had previously only applied to large corporations. The fact that the ceiling was now being lowered allowed for a higher tax revenue to the government without the need for them to propose and pass a separate new law. The government's lowering of the ceiling was proclaimed to be an effort to make Ukrainian small businesses more equitable on the world stage. The government claimed that by taking this measure, they would not be subjected to claims from outside governments that their small businesses could not fairly compete against Ukraine small businesses due to excessive tax breaks. 
For Mihail, the immediate question was the extent to which the new ceiling would be enforced. He may be able to get a government exemption or to use accounting methods that decreased his gross profit for reporting purposes. He planned to make inquiries very quietly but quickly with the numerous friends he had cultivated in government offices.

\section{Another Business Adjustment}

Eventually, Mihail decided that the risk of working under special government privilege was too risky. He could not be certain of loyalties, opinions or feelings. Additionally, he was able to contrast the last 18 months of turmoil and uncertainty with the first twelve years in business and he realized he did not want to enter into another stressful period of rampant uncertainty.

Instead, following in the footsteps of many other entrepreneurs in his home town and across the country, Mihail chose to decrease his level of export sales. Mihail was a savvy enough business man, and had learned much in the last six years, and was able to decrease exports without angering existing clients. In this regard, Mihail remained hopeful of being able to rebuild and grow his business again in the future. Meanwhile, he also had to watch as several colleagues thrived. Many other small business owners found varying ways to avoid the tax and continue to grow and increase net profits. While he knew that many might be honest and fortunate, he was aware that the majority had simply paid officials to ignore the discrepancies in their accounting reports.

For many of the local and national government officials, the increase in tax revenue was enough to help their ailing budgets. They saw nothing wrong with the idea of also increasing their own financial situation. They viewed this as a win-win-win situation. They did not believe that the fact that the government could be collecting even higher tax levels from businesses was relevant or necessary.

\section{New Breed}

However, there was a new breed of young professionals in the Ukrainian business arena. Mihail was representative of a new approach to the entrepreneurial spirit. He was able to balance the economic and political situation into a cohesive unit that supported and respected the other side of the business table. He hired a graduate student from the local university who had studied accounting. Although this first accounting new hire had to be let go within his first year of employment, Mihail had learned enough from him to begin maintaining his own account records.

The graduate student had sold business information and bids to Mihail's direct competitors. Mihail's perseverance against so many levels of corruption and disappointment have distinguished him, and others like him, as the hope for building a profitable, capitalistic business model that will have a sustainable long term approach.

\section{Discussion Points}

To Begin: Spend time looking at a map and locate Ukraine, its neighbors, its geography and topography. Identify important statistical information. What statistics do you think are most relevant to a beginning level of knowledge about the Ukraine? (i.e.: GDP, education levels, literacy, median age, population, etc.)

\section{QUESTIONS}

1. Was Mihail's background, growing up in a communist country and not having travelled, relevant to him becoming an entrepreneur?

2. Do you think Mihail would have been more or less successful without having spent time on the early political connections?

3. How could this situation have changed if Mihail had been sourcing lumber from outside the Ukraine earlier?

4. Were the new laws good or bad and for whom?

5. The last page discusses a win-win-win situation. Is this an accurate assessment? 
6. What are the main ethical issues present in this case?

7. Did Mihail make the right decision? Why or why not? Were his decisions based on good reasoning, fear, lack of business expertise or something else?

Summarizing: What do you think the next 5 years will look like for Mihail and the lumber market?

\section{AUTHOR INFORMATION}

Dr. S. Daly is an Assistant Professor of Business at Lindenwood University in St. Charles, Missouri, USA. Dr. Daly has worked and lived in several Eastern European countries, was awarded an AACSB fellowship, and spent almost a decade in the aerospace industry. E-mail: sdaly@lindenwood.edu. Corresponding author.

Ms. Mariia Les received her MBA degree with an emphasis in marketing from Lindenwood University in St. Charles, Missouri. Ms. Les was born in Ukraine and moved to the United States at the age of 17. After she graduated in 2011, Ms. Les moved to Chicago, Illinois, where she will pursue her career goals. E-mail: Mles9@ yahoo.com 